\title{
MASA syndrome in twin brothers: case report of sixteen-year clinical follow up
}

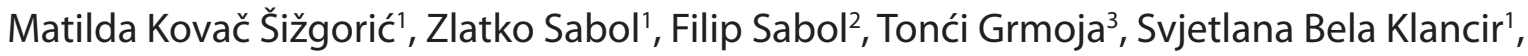 \\ Zdravka Gjergja' ${ }^{1}$, Ljiljana Kipke Sabol ${ }^{1}$
}

MASA syndrome (OMIM 303350) is a rareX-linked recessive neurologic disorder, also called CRASH syndrome, spastic paraplegia 1 and Gareis-Mason syndrome. The acronym MASA describes four major signs: Mental retardation, Aphasia, Shuffling gait and Adducted thumbs. A more suitable name for this syndrome is $L 1$ syndrome because the disorder has been associated with mutations in the neuronal cell adhesion molecule L1 (LICAM) gene. The syndrome has severe symptoms in males, while females are carriers because only one X chromosome is affected. The aim of this report is to show similarities and differences in clinical manifestations between twins with the L1CAM gene mutation and to emphasize the importance of genetic counseling. Our patients were dizygotic twins born prematurely at 35 weeks of gestation. Pregnancy was complicated with early bleeding and gestational diabetes. Immediately after birth, hypertonia of lower extremities was observed in both twins. Sixteen-year clinical follow up showed spastic paraparetic form with shuffling gait, clumsiness, delayed speech development, lower intellectual functioning at the level of mild to moderate mental retardation, primary nocturnal enuresis, behavioral and sleep disorder (more pronounced in the second twin). Magnetic resonance imaging of the brain showed complete agenesis of the corpus callosum, complete lack of the anterior commissure, and internal hydrocephalus. Electroencephalograms showed nonspecific slower dysrhythmic changes. Kidney ultrasound showed mild dilatation in the channel system of both kidneys in both twins. Ophthalmologic examination was normal. Molecular genetic testing identified homozygous intron 26 L1CAM gene IVS26-12G $\rightarrow$ A mutation in both twins. The mother is carrier of the same heterozygous mutations. In conclusion, our patients, fraternal twins, show similar clinical changes typical of the MASA syndrome. After identifying the specific genetic mutations, this family has become eligible for genetic counseling and informative for prenatal diagnosis.

Keywords: MASA (Mental Retardation, Aphasia, Shuffling Gait, Adducted Thumbs) Syndrome; mutation; genes; twins

\section{INTRODUCTION}

MASA syndrome (OMIM 303350) is a rare X-linked recessive neurologic disorder also called CRASH syndrome and Gareis-Mason syndrome, spastic paraplegia 1. A more suitable name for this syndrome is L1 syndrome because the disorder has been associated with mutations in the neuronal cell adhesion molecule L1 (L1CAM) gene. The syndrome has severe symptoms in males, while females are carriers because only one X chromosome is affected. Only 5\% of women with L1CAM mutation have clinical symptoms of the disease. The incidence is 1 per 25000 to 60000 males.

The acronym MASA describes four major signs: Mental retardation, Aphasia, Shuffling gait and Adducted thumbs. Second acronym describing this syndrome is CRASH syn- drome named after corpus callosum hypoplasia, mental retardation, adducted thumbs, spastic paraplegia and hydrocephalus (1). The following symptoms may also be diagnosed: hydrocephalus, agenesis of the corpus callosum, drinking/swallowing/feeding problems in infants and chil-

\footnotetext{
${ }^{1}$ Outpatient Clinic for Children Dr. Sabol, IV. Cvjetno naselje 21, Zagreb, Croatia

${ }^{2}$ Department of Psychiatry, University Hospital Center Zagreb and University of Zagreb, School of Medicine, Zagreb, Croatia ${ }^{3}$ Departmet of Radiology, Children's Hospital Zagreb, Zagreb, Croatia

Correspondence to:

Matilda Kovač Šižgorić, MD., Outpatient Clinic for Children Dr. Sabol, IV. Cvjetno naselje 21, 10000 Zagreb, Croatia;

e-mail: poliklinika.sabol@zg.t-com.hr, matilda.kovac.sizgoric@zg.t-com.hr

Primljeno/Received: 1. 10. 2014., Prihvaćeno/Accepted: 29. 10. 2014.
} 
dren, hypertonia, primitive tongue movements, defects of the spine, diminished growth, slightly peculiar (different) facial expressions and excessive salivation, prominent forehead, and flat feet. The severity of these abnormalities is highly variable, sometimes even within the same family (2).

The first report of this syndrome appeared in 1974 by Bianchine and Lewis (3) and since then more than 200 different mutations have been described.

The gene for human L1CAM is located in the Xq28 region of the $X$ chromosome. Most L1CAM mutations reported to date are point mutations. In the normal nervous system, the synthesis and neurotrophic function of $L 1$ is controlled by positive feedback loop which consists of $L 1, L 1$ sheddases, gamma-secretase, L 1 extracellular domain (L1ED), L 1 cytoplasmic domain (L1CD), and transcriptional factor Pax6. The mutation in L1ED or L1CD will disrupt this feedback loop and inhibit the synthesis and neurotrophic function of L1 (6).

The neuronal cell adhesion molecule L1 (L1CAM) is a transmembrane glycoprotein belonging to the immunoglobulin superfamily and is essential in the development of the nervous system. It is mainly expressed on neurons and Schwann cells, and plays a key role in myelination, axon fasciculation, growth cone morphology, axon outgrowth and pathfinding and neuronal migration through interactions with various extracellular ligands and intracellular second messenger systems (1). In addition, L1 is involved in regeneration of damaged nerve tissue, and has been implicated in longterm memory formation and establishment of long-term potentiation in the hippocampus $(4,5)$.

\section{CASE REPORT}

We report on fraternal twin brothers born to healthy and non-related parents that were clinically followed up for 16 years. They were born prematurely at 35 weeks of gestation from pregnancy complicated with early bleeding and ges- tational diabetes. The first twin birth weight was $1990 \mathrm{~g}$, birth length $47 \mathrm{~cm}$, Apgar score 3/8/10, and second twin birth weight was $2240 \mathrm{~g}$, birth length $44 \mathrm{~cm}$, Apgar score 9/10/10. Immediately after birth, hypertonia of lower extremities with adducted thumbs was observed in both twins. Agenesis of the corpus callosum was detected by ultrasound in both twins.

Early psychomotor development was delayed in both twins. They attended neurodevelopmental assessment and physiotherapy. Hypertonia of lower extremities, observed at birth, during the years of follow up was replaced by spastic paraparetic form with shuffling gait, more prominent in second twin. Tendon reflexes were increased only on lower extremities with positive extensor plantar response. Besides clumsiness, hand function was disturbed because of adducted thumbs, as the result of hypoplasia of the extensor pollicis longus or brevis, more prominent on the left hand of both twins (Figure 1). Sphincter control was adopted around six years of age. Both twins manifested primary nocturnal enuresis. Kidney ultrasounds showed mild dilatation in the channel system of both kidneys in both twins. They had problems with control of auto-aggression, sleep disorder (more pronounced in the second twin) and delayed speech development (attended speech and language therapy). Cognitive problems were observed and their mental functioning was at the level of mild to moderate mental retardation. Physical growth and development of the twins was different. The height of the first twin (age 16) is above $97^{\text {th }}$ percentile and of the second twin at $75^{\text {th }}$ percentile. Shuffling gait and adducted thumbs with distinct facial appearance of the twins was a diagnostic clue to further investigation.

In both twins, magnetic resonance imaging (MRI) of the brain showed complete agenesis of the corpus callosum, complete lack of the anterior commissure, and internal hydrocephalus without the need of surgical intervention (Fig-

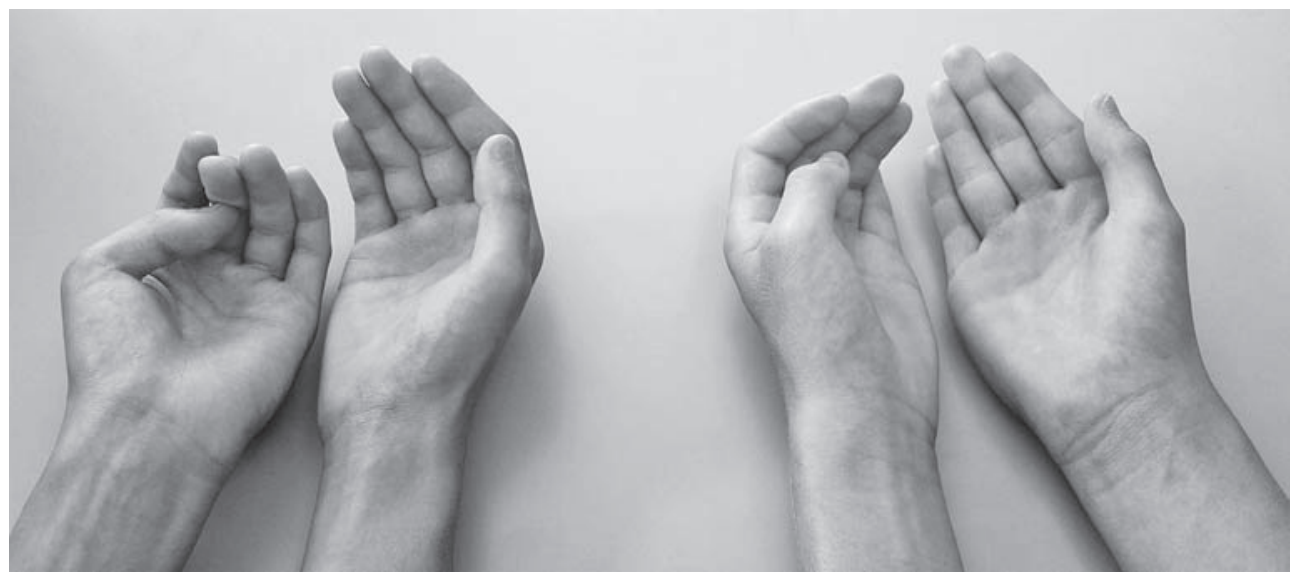

FIGURE 1. Adducted thumbs, more prominent on the left hand of both twins 

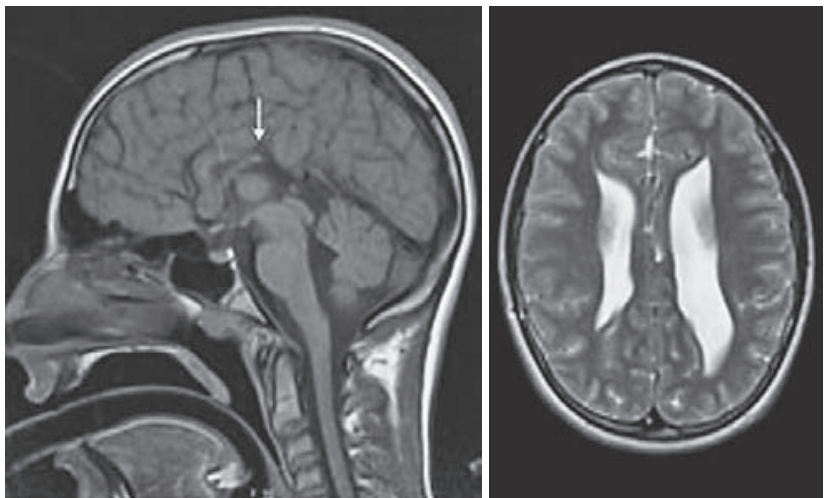

FIRST TWIN
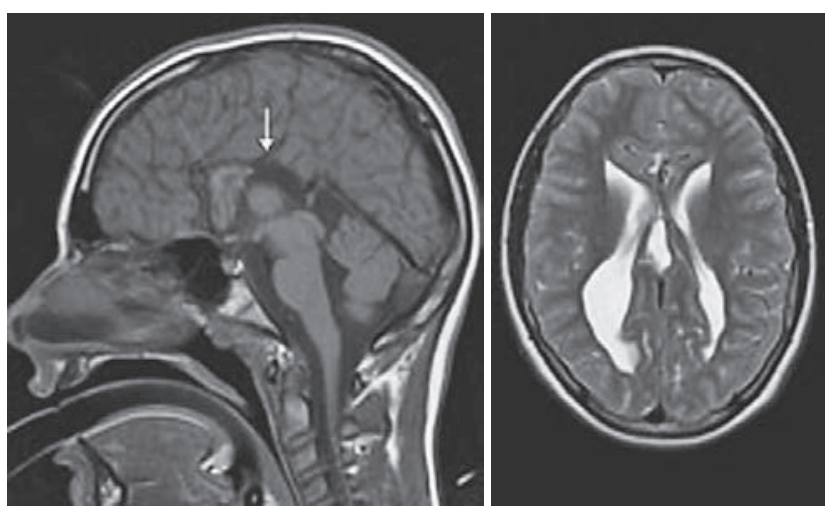

SECOND TWIN

FIGURE 2. Magnetic resonance image of the brain showed complete agenesis of the corpus callosum, complete lack of the anterior commissure, and internal hydrocephalus in both twins

ure 2). Electroencephalograms (EEGs) showed nonspecific slower dysrhythmic changes without epileptiform abnormalities.

Molecular genetic testing was done at Karl-Franzens Universität Graz. The homozygous intron 26 L1CAM gene mutation IVS26-12G $\rightarrow$ A was identified in both twins. The mother is carrier of the same heterozygous mutation.

Both twins were trained by special programs (currently completing training for auxiliary painters). The boys have been very well socially adjusted, giving an impression of warm and happy young people.

\section{DISCUSSION}

In this case report, we describe dizygotic male twins with MASA syndrome caused by L1CAM mutation. L1CAM mutations can be classified into three groups based on how they would affect the expression or structure of the protein (6). The first class of mutation includes missense mutations, nonsense mutations, frame shifts, duplications and deletions that affect only the cytoplasmic domain of L1 at the C-terminal end of the protein. The second class consists of missense point mutations in the extracellular domain. The third class of mutations includes nonsense or frame shift mutations that produce a premature stop codon in the extracellular domain of $L 1$. This would result in the $L 1$ failing to remain associated with the cell surface due to the loss of its transmembrane domain. Over 200 mutations in L1CAM have been reported; however, only a few large gene deletions have been observed (7). The intronic mutation IVS27$12 \mathrm{G} \rightarrow$ A detected in our patients was diagnosed by Brunner-Krainz et al. (8) and has been recorded for the first time in 1995 by Jouet et al. with a very similar clinical phenotype (9). It is of interest to note that single point mutation in each of the members of the same family, as presented in our cases report, results in variable clinical phenotypes, suggesting that the phenotypic expression of the L 1CAM gene is influenced by other genetic or environmental factors. This observation may then explain the absence of a definitive phenotype-genotype correlation in these $\mathrm{X}$-linked syndromes (10).

Hereditary spastic paraplegias are a group of very heterogeneous disorders, both clinically and genetically, which are characterized by progressive spasticity of lower extremities. Hereditary spastic paraplegias are considered uncomplicated if only progressive spasticity is the major clinical sign, or complicated if spasticity of lower extremities is associated with other clinical features. Spastic paraplegia 1 (SPG 1) is also called MASA syndrome and according to the previously mentioned criteria MASA syndrome belongs to complicated hereditary spastic paraplegias. Shuffling gait in our patients is probably caused by spasticity of lower extremities, although typically shuffle is present in patients with extrapyramidal disorders.

X-linked congenital hydrocephalus may be caused by $\mathrm{X}$ linked aqueductal stenosis (HSAS), which was not the case in our patients.

Among the major signs, hydrocephalus found in our patients is often categorized into three basic groups according to the severity: severe, moderate or absent. Severe hydrocephalus is defined as ventricular enlargement that requires ventriculoperitoneal shunt, cerebrospinal fluid (CFS) drainage, hydrocephalus diagnosed in utero or described as progressive hydrocephalus having aqueductal stenosis. Patients with normal head circumference who are not described as being hydrocephalic or who showed no ventricular dilatation on imaging studies are defined as 'absent' concerning hydrocephalus. Our patients were in the moderate group including those that are normocephalic or mildly macrocephalic requiring no shunting procedure. According to the literature, there are about $26 \%$ of patients with MASA syndrome who have moderate hydrocephalus (6).

A wide variety of brain malformations have been reported in association with X-linked hydrocephalus, including agen- 
esis of the corpus callosum or septum pellucidum, found in our patients, fusion of the thalamic fornices, colliculi and corpora quadrigemina, and absence or hypoplasia of the corticospinal tract, as assessed by histologic analysis of the pyramids in cross sections of the medulla. The latter observation provides an explanation for the spasticity present in this disease, as increased tone with hyperreflexia are characteristic signs of corticospinal tract damage.

Also, a variety of ocular, musculoskeletal and neurologic abnormalities have been reported including nystagmus, ptosis, optic atrophy, scoliosis, torticollis, lumbar lordosis and seizures. Flexion-adduction deformities of the thumbs are frequently but not always observed. Halliday et al. (10) report on elapsed thumbs in $44 \%$ of cases and may be associated with agenesis or hypoplasia of the abductor or extensor muscles of the thumbs. In patients with MASA syndrome, mental retardation is often classified into two groups: severe (IQ below 50) and modest (IQ above 50). Our twins have mild to modest mental retardation, which is found in $76 \%$ of these patients (6).

In the literature, we found no report on a long follow up of MASA syndrome in mono- or dizygotic twins. In monitoring patients with this syndrome, it is best to involve a multidisciplinary team with expertise in pediatrics, child neurology, medical genetics, neurosurgery, rehabilitation and speech therapy. Shunting of the corticospinal tract should be performed as needed to reduce intracranial pressure. Surgery for adducted thumbs is not indicated. In some milder cases, tendon transfer and/or splint may improve thumb function.

MASA syndrome is an X-linked inherited disease. Women who are carriers have a $50 \%$ chance of transmitting the disease-causing mutation in each pregnancy. Sons who inherit the mutation will be affected; daughters who inherit the mutation will be carriers. Genetic testing of at risk female relatives and prenatal testing are possible if the L1CAM disease-causing mutation has been identified in an affected family member (11).

\section{CONCLUSION}

Our patients, dizygotic twins, show similar clinical changes typical of MASA syndrome. After identifying the specific genetic mutations, this family has become informative for prenatal and preimplantation genetic diagnosis, mostly because the family has a healthy girl. At present, the parents refuse genetic testing in their daughter. As testing methodology and our understanding of the genes, mutations and diseases is likely to improve in the future, consideration should be given to banking DNA of affected individuals.

\section{Abreviations:}

L1CAM - neuronal cell adhesion molecule L1

MASA syndrome - Mental retardation, Aphasia, Shuffling gait and Adducted thumbs

\section{NOVČANA POTPORA/FUNDING \\ Nema/None}

\section{ETIČKO ODOBRENJE/ETHICAL APPROVAL}

Nije potrebno/None

\section{DOPRINOSI AUTORA/DECLARATION OF AUTHORSHIP}

Kovač Šižgorić M., Sabol Z., Bela Klancir S. - pretraživanje literature, prikupIjanje, analiza i tumačenje podataka/literature search, data collection, analysis and interpretation

Sabol F., Kipke Sabol Lj. - praćenje psihomotornog razvoja i školska postignuća djeteta/monitoring psychomotor development and school achievements of the child

Gjergja Z. - kardiološka evaluacija/cardiologic evaluation

Grmoja T. - tumačenje neuroradioloških pretraga/interpretation of neuroradioog/interpretation of neuroradiologic data

\section{SUKOB INTERESA/CONFLICT OF INTEREST}

Autori su popunili the Unified Competing Interest form na www.icmje.org/ coi_disclosure.pdf (dostupno na zahtjev) obrazac i izjavljuju: nemaju potporu niti jedne organizacije za objavljeni rad; nemaju financijsku potporu niti jedne organizacije koja bi mogla imati interes za objavu ovog rada u posljednje 3 godine; nemaju drugih veza ili aktivnosti koje bi mogle utjecati na objavljeni rad./All authors have completed the Unified Competing Interest form at www.icmje.org/coi_disclosure.pdf (available on request from the corresponding author) and declare: no support from any organization for the submitted work; no financial relationships with any organizations that might have an interest in the submitted work in the previous 3 years; no other relationships or activities that could appear to have influenced the submitted work.

\section{REFERENCES}

1. Fransen E, Van Camp G, Vits L, Willems PJ. L1-associated diseases: clinical geneticists divide, molecular geneticists unite. Hum Mol Genet. 1997;6:1625-32. http://dx.doi.org/10.1093/hmg/6.10.1625

2. Serville F, Lyonnet S, Pelet A, et al. X-linked hydrocephalus: clinical heterogeneity at a single gene locus. Eur J Pediatr. 1992;151:515-8. http://dx.doi.org/10.1007/BF01957757

3. Bianchine JW, Lewis RC. The MASA syndrome - a new heritable mental retardation syndome. Clin Genet. 1974;5:298-306. http://dx.doi.org/10.1111/j.1399-0004.1974.tb01697.x

4. Martini R, Schachner M. Immunoelectron microscopic localization of neural cell adhesion molecules (L1, N-CAM, Myelin-associated Glycoprotein) in regenerating adult mouse sciatic nerve. J Cell Biol. 1988;106:1735-46. http://dx.doi.org/10.1083/jcb.106.5.1735

5. Luhti A, Laurent JP, Figurov A, Muller D, Schachner M. Hippocampal long-term potentiating and neural cell adhesion molecules L1 and NCAM. Nature. 1994;372:777-9.

http://dx.doi.org/10.1038/372777a0

6. Yamasaki M, Thompson P, Lemmon V. CRASH syndrome: Mutations in L1CAM correlate with severity of the disease. Neuropediatrics. 1997;28:175-8. http://dx.doi.org/10.1055/s-2007-973696

7. Chidsey BA, Baldwin EE, Toydemir R, Ahles L, Hanson H, Stevenson DA. L1CAM whole gene deletion in a child with L1 syndrome. Am J Med Genet A. 2014;164A:1555-8. http://dx.doi.org/10.1002/ajmg.a.36474 
8. Brunner-Krainz M, Fahsold R, Maurer-Fellbaum U, Plecko B. MASA (mental retardation, aphasia, shuffling gait, adducted thumbs): Intronic mutation of L1CAM gene in male twins. Neuropediatrics. 2005;36:P29

9. Jouet $M$, Moncla A, Paterson J, et al. New domains of neural cell-adhesion molecule L1 implicated in X-linked hydrocephalus and MASA syndrome. Am J Hum Genet. 1995;56:1304-14.

10. Ruiz JC, Cuppens H, Legius E, Fryns JP, Glover T, Marynen P, Cassiman JJ. Mutations in L1-CAM in two families with $\mathrm{X}$ linked complicated spastic paraplegia, MASA syndrome, and HSAS. J Med Genet. 1995;32:549-52. http://dx.doi.org/10.1136/jmg.32.7.549

11. Halliday J, Chow CW, Wallace D, Danks DM. X linked hydrocephalus: a survey of a 20 year period in Victoria, Australia. Med Genet. 1986;23:23-31. http://dx.doi.org/10.1136/jmg.23.1.23

12. Schrander-Stumpel C, Vos YJ. At GeneReviews Seattle (WA): University of Washington, Seattle; 1993-2014.

\title{
SAŽETAK
}

\section{MASA sindrom u braće blizanaca: prikaz kliničkog praćenja kroz šesnaest godina}

\author{
M. Kovač Šižgorić, Z. Sabol , F. Sabol, T. Grmoja, S. Bela Klancir, Z. Gjergja, Lj. Kipke Sabol
}

Sindrom MASA (OMIM 303350), nazvan još i CRASH sindrom, nasljedna spastička paraplegija 1 i Gareis-Masonov sindrom, je X-vezana, recesivno naslijedna bolest. Akronim „MASA" opisuje četiri glavna klinička znaka - mentalnu retardaciju, afaziju, poremećaj hoda (shuffling gait ), pri čemu bolesnik hoda vrlo sporo, povlači stopala, a ne odiže ih od podloge i aducirane palčeve. Pogodniji naziv za ovaj sindrom je "L1 sindrom". Ovo odstupanje je povezano s mutacijom gena L1CAM. Budući da je zahvaćen samo jedanX kromosom, u ovom sindromu nalazimo umjerene do teške simptome u muškaraca, dok su žene prenositeljice. Cilj ovog rada je pokazati sličnosti i razlike kliničkih manifestacija u blizanaca s mutacijom gena LICAM i istaknuti važnost genetičke obrade bolesnika za genetsko savjetovanje obitelji. Naši bolesnici, dvojajčani blizanci, rođeni prijevemeno u 35. tjednu gestacije. Trudnoća je komplicirana ranim krvarenjem i gestacijskim dijabetesom. Neposredno nakon rođenja uočen je hipertonus donjih ekstremiteta u oba blizanca. U tijeku šesnaestogodišnjeg praćenja u kliničkom statusu pokazali su motoričko odstupanje u vidu spastičkog paraparetskog obrasca hoda, nespretnost, usporen razvoj govora, intelektualno funkcioniranje na razini blaže do umjerene mentalne retardacije, primarnu noćnu enurezu, poremećaj ponašanja i spavanja (više izražene u drugog blizanca). MRI mozga blizanaca pokazao je kompletnu ageneziju korpusa kalozuma, kompletni nedostatak prednje komisure i interni hidrocefalus. U EEG-u su, uz spori osnovni ritam, registrirane dizritmične promjene. Ultrazvuk bubrega blizanaca pokazao je umjerenu dilataciju kanalnog sustava oba bubrega. Oftalmološki pregled je bio uredan. Molekularnim genetičkim testiranjem utvrđeno je da su blizanci homozigotni nositelji mutacije IVS26-12G $\rightarrow$ A u intronu 26 LICAM gena. Majka je heterozigotna nositeljica iste mutacije. Naši bolesnici, dvojajčani blizanci, pokazali su slične kliničke značajke tipične za sindrom MASA. Nakon utvrđivanja specifične genske mutacije ova obitelj postala je podobna za genetsko savjetovanje i informativna za prenatalnu dijagnostiku.

Ključne riječi: MASA (mentalna retardacija, afazija, poremećaj hoda, aducirani palčevi) sindrom; mutacija; geni; blizanci 